\title{
THE SCIENCES AND THE HUMANITIES
}

\section{Conflict and Reconciliation}

\author{
by $W . T$. Jones
}

UNIVERSITY OF CALIFORNIA PRESS

BERKELEY AND LOS ANGELES I 967 
UNIVERSTTY OF CALIFORNIA PRESS

BERKELEY AND LOS ANGELES, CALIFORNIA

CAMBRIDGE UNIVERSITY PRESS

LONDON, ENGLAND

(C) I 965 BY THE REGENTS OF THE UNIVERSITY OF CALIFORNIA LIBRARY OF CONGRESS CATALOG CARD NUMBER: 65-24I79

FIRST CALIFOR NIA PAPERBOUND EDITION, 1967

PRINTED IN THE UNITED STATES OF AMERICA 
For M M J 



\section{PREFACE}

THIs воor has been in gestation as long, comparatively speaking, as an elephant. During all this time 1 have had much advice and criticism, for which $I$ have now the pleasure of recording my thanks.

Fifteen years ago, when I was writing $A$ History of Western Philosophy, it became clear to me that the whole modern period-not merely in philosophy, but in every aspect of the culture-has been marked by an increasing tension between the new scientific view of man and the traditional humanistic view; and I concluded that the reconciliation of these conflicting views had become a matter of urgency, not merely for professional philosophers but for men and women everywhere. At the outset, however, I formulated the difficulty as the problem of finding a place for values in the world of fact. I did not make much progress until it occurred to me that this definition was culture-bound-was, indeed, a reflection of the predominance in our society of scientific ways of thinking. It makes as much sense to talk about the need of finding a place for facts in the world of values; indeed, in some cultures this would be the natural way of formulating my problem.

Shortly after making this discovery, I had the good fortune to receive a Guggenheim Fellowship; the generosity of the Foundation enabled me to produce a complete draft in a far shorter time than would otherwise 
have been possible. And in $1961 \mathrm{I}$ had an opportunity to try out parts of four chapters of this draft (i, ii, v, vii), when I was invited to give the Knoles Lectures at the University of the Pacific. I am most grateful to the University, and to Professor William D. Nietmann in particular, for their cordial hospitality, for the provision of a splendid array of critics, and for permission to use material from Facts and Values, the published version of my lectures. In 1963-64 I tested still more chapters in a series of lectures I gave as Phi Beta Kappa Visiting Scholar at a number of universities and colleges. I am grateful to all those, most of whom I can identify only as members of the audience, whose questions and challenges have helped me improve the book. They have made me see more clearly both what I had to say (which was not always, at least at the outset, what I wanted to say) and also how to say it (which was often not how I had originally said it).

I have also presented parts of the manuscript at meetings of the Claremont Philosophical Discussion Group. For vigorous discussions at these meetings and for reading the manuscript, in whole or in part, in one or the other of several drafts, I thank many friends and colleaguesamong them Morton Beckner, James Doyle, Stephen Erickson, Robert Fogelin, Josiah Gould, Douglas Greenlee, John Hospers, Oliver Johnson, Gordon Kaufman, Stephen Pepper, Philip Rhinelander, Frederick Sontag, W. T. Stace, Tracy Westen, and John Wilkinson. In particular, I am much indebted to Theodore Greene and Edwin Fussell for the enormously detailed comments that each of them sent me-the former on the earliest version, the latter on the last but one. Geoffrey Ashton of the University of California Press has saved me from a number of egregious slips and has greatly helped me in other ways.

In addition, I am grateful to the Research Committee of Claremont Graduate School and University Center for grants over a number of years; to Mrs. Dorothy Overaker and Mrs. Frances Gentile, who have done most of the typing; and to my wife, who has helped me read proof.

Finally, I must thank the following publishers and authors for permission to quote from copyrighted works:

Appleton-Century-Crofts for Ernest R. Hilgard's Theories of Learning. Basil Blackwell, Ltd., for John Wisdom's Philosophy and Psychoanalysis.

The Beacon Press for John Dewey's Reconstruction in Philosophy. 
J. M. Dent \& Sons, Ltd., and the Trustees of the Joseph Conrad Estate for Joseph Conrad's Heart of Darkness.

Faber \& Faber, Ltd, and Harcourt, Brace \& World, Inc., for T. S. Eliot's The Waste Land, The Cocktail Party, Murder in the Cathedral, "Gerontion," and "Burbank with a Badaeker: Bleistein with a Cigar."

Harper \& Row, Inc., for Edward Weismiller's "College Town."

Harper \& Row, Inc., and Curtis Brown, Ltd., for Joyce Cary's The Horse's Mouth.

Alfred A. Knopf, Inc., and Martin Secker \& Warburg, Ltd., for Thomas Mann's The Magic Mountain.

Alfred A. Knopf, Inc., for Albert Camus' The Stranger.

Vladimir Nabokov and Weidenfeld \& Nicolson, Ltd., for Mr. Nabokov's Bend Sinister.

New American Library of World Literature, Inc., for John Ciardi's translation of The Inferno.

Philosophical Library, Inc., for Herbert Feigl's "Logical Empiricism." Random House, Inc., and Chatto \& Windus, Ltd., for William Faulkner's "The Bear" (Copyright 1942 by The Curtis Publishing Co., Copyright 1942 by William Faulkner; reprinted from Go Down, Moses by William Faulkner, by permission of Random House, Inc.) and "Old Man" (Copyright 1939 by Random House, Inc.; reprinted from The Faulkner Reader, by permission).

May Sarton for her "The Writing of a Poem"; Miss Sarton and W. W. Norton \& Co., Inc., for her "On Being Given Time." 
